\title{
The Art of Translating Similes in the Works of Central Asian Writers
}

\author{
Nasiba Iskanova Parmonovna ${ }^{a}$, Saodat Khasanova Kayumovnab ${ }^{b}$, Khudoyorova Dildora Najmiddinovna

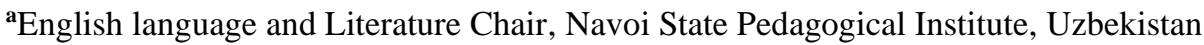 \\ ${ }^{\mathbf{b}}$ English language and Literature Chair, Navoi State Pedagogical Institute, Uzbekistan \\ 'Foreign Languages Chair, Navoi State Pedagogical Institute, Uzbekistan
}

Article History: Received: 11 January 2021; Accepted: 27 February 2021; Published online: 5 April 2021

\begin{abstract}
The topic is translating some stylistic devices in both English and Uzbek in order to develop sociocultural communicative competence and integrated skills of language learners. This article provides a brief overview of these approaches as well as methods for translating them. Some examples of simile from well-known writers' literary works are also provided here.
\end{abstract}

Key words: stylistic devices, simile, language learner, nation, communication, practice, translation.

\section{Introduction}

Translation is the process in which a written communication or a text in a first language is produced as the written communication or text in the second language interpreting the same meaning. Here the text in the first language is the "source text" and the equivalent text that communicates the same message is the "target text" or "translated text". Initially translation has been a manual activity. Today, together with manual translation, there is also automatic translation of natural-language texts, which is referred to as machine translation or computer-assisted translation, which use computers as an aid to translation. Translation is one way to bring the world closer.

The main aim of any translator is to convey both the semantic meaning of work and cultural component to meet the demands of readers to get acquainted with the world picture of other people through the author's vision. From this point, cultural information constitutes the major difficulty in translating, and cultural factors should never be neglected as far as translation is concerned. To succeed in translating culturebound elements translator can use any applicable strategy or, as they are overlapping with each other, use some of them together. [5, p10]

Translator must convey adequately the national character connected with the real representation of life. It means that he must know social conditions and nation development whose literature he translates, he must know and understand the specific spiritual way of life, find explanations of problems caused with peculiarities of this nation and originality of his development. Translation is not only outward form of these mutual relations; it is also dialectic unity of the national and international coloring of its essence.

2. Materials and methods. Translating literary works simply means changing a text in one language to a text in another based on the rules of that language. In this case, the word is distinguished by the fact that it forms a compound, has synonyms, antonyms, idioms, proverbs, forms phraseological units, is used in a figurative sense. The biggest problem with translation is clarifying the differences and similarities between cultures. Residents of a certain culture look at something from their own point of view. Words that appear as equivalents may not be equivalent. Different cultures have different directions. For example, in the culture of Uzbekistan gardening, agriculture, domestic animals and everyday life are of great importance, and in England and America, attention is paid to income, celebrations, financial talk, sports and benefits. Some societies are more technically oriented, others less technically oriented. We have chosen some literary texts in order to translate and to compare stylistic devices in three languages. Similes are used in literature to make writing more vivid and powerful. In everyday speech, they can be used to convey meaning quickly and effectively, as many commonly used expressions or idioms are similes.

For example, when someone says "He is as busy as a bee," it means he is working hard, as bees are known to be extremely busy. By comparing this sentence with Uzbek language, we use an ant instead of bee. Russian people also use "муравей” as bee in their daily life. 
"Odamning ruhida shu qadar yengillik paydo bo'ladiki, xuddi, qanot chiqazib olis ufqlarga uchib ketging keladi..." (O'tkir Xoshimov, "Nur borki, soya bor" G'afur G'ulom nomidagi Adabiyot va san'at nashriyoti, 1977 yil, 15 bet)

There is so much relief in the human soul that you want to take off your wings like a bird and fly to the distant horizons.

In three languages, we can see the same translation of simile. Bird-qush-птица. The basic purpose of translation is to reproduce various types of texts, comprising literary, religious, scientific, philosophical texts etc. in another language and thus making them available to wider readers, to a greater number of target audiences and to bring the world closer.

Birinchi kursda o'qib yurganida, Elmira guldek qiz edi. Hech kimni pisand qilmasdi. ...

( O’tkir Xoshimov, "Nur borki, soya bor" G'afur G'ulom nomidagi Adabiyot va san'at nashriyoti, 1977 yil, 126 bet)

When she was a freshman, she was so beautiful like a flower. She ignored everybody.

Here, without any difficulties, we can easily compare the girl with a flower in three languages. A flower (English)-gul (Uzbek)-цветок (Russian)

1. Salqinda qop-qora sochlari oq kaptarning patiday bo lib ketdi.- [1,p3] На морозе его черные волосы словно превратились в перья белого голубя.

In cool weather, her tin black hair turned into ruffled like a white dove's feather.

2. Bolalaigini eslatadigan guvala devorlar bilan qurshalgan ko`chalar, cho`milgan jimjit soylar, olisda sadafdek chaqnab turgan cho`qqilar, yam-yashil o`tloqlar ko`ngliga taskin berarku. [1, p3] Улицы, окруженные стенами, тихие ручьи, вершины словно блестящие жемчуга вдали, сочные зеленые луга обнадеживая напоминали ему детство.

Probably, the streets surrounded by walls, silent streams, peaks glistening like pearls in the distance, green meadows which can make him relief.

3. Oppoq bulutlar sut ko`pigidek bo`lib, qishloq ustidan shoshilmay toqqa qarab suzib o`tib ketishardi. [1, p4]

Белье как молочная пенка облака, медленно пльли над деревней в сторону гор.

The white clouds like milk bubbles were floating slowly over the village towards the mountains.

4. Nihoyat jimjit sertuproq ko`chalarda kezib, muhabbatining bir umr unitilmas kuyidek ko`ngilni yayratuvchi, g`azaldek yurakka quyiluvchi, tushdek tumanli onlarini kechirgan.

$[1, \mathrm{p} 4]$

Наконец он бродил по тихим пыльным улицам, наслаждаясь моментами своей любви, незабываемыми как вечная песня, сердечными как газель, и туманными как сон.

At last, he felt as if he was wandering in the quiet and dusty streets, giving pleasure like a love tune, which were unforgettable, enjoyable as hearty as a gazelle, and as foggy as a dream.

5. Elektro payvandning o`tkir nuri azamat teraklarning uchini sham piligidek bir dam yonib o chirdi. $-[1, p 6]$

The bright light of the electric welding flashed at the peak of the huge poplars like a candle.

Яркий свет электросварки резко вспыхнул как свеча на макушках огромных тополей.

In one sense, communicative translation, by adapting and making the thought and cultural content of the original more accessible to the reader, gives semantic translation another dimensions.

6. Zebining yuzidagi - oyday tiniq va quyoshday yorug` bu holat moddiy haqiqatlar qadar ochiq ko’rinardi. [6, p 6]

Лицо Зеби было безупречным как луна, ярким как солнце и это состояние являлось ясным как день.

Zebi's facial expression became as clear as the moon, as bright as the sun and as clear as the realities.

7. - Bu nima qiyomat!!! - deb shovqin solishi ikkala yosh qizni, chaqmoq tekkan daraxtday, turgan joylarida qotirib qo`ydi. [6, p 10]

Фраза: «Это что ещзе за балаган!» застала обоих девущек врасплох, и они остолбенели словно деревья, поражённье молнией.

His cry: "What a doomsday!" - made the two girls lifeless and motionless, like a tree struck by lightning.

The closer the cultural overlap among three languages-this overlap being more important than the structural attraction or the geographical propinquity of the three languages, but the translator's empathy being the most important factor of all, the closer, better, the translation is likely to be. 
8. Bunday telbalarcha ko`prib-toshuvlarni to`xtatmoq uchun ham, albatta telbalarcha hayqirishlar, chaqmoq qadar qudratli zarbalar lozim bo`lardi. [6, p 10]

Для того чтобы остановить такой беспорядок, конечно потребуются безумные крики и удары мощзные как молния.

In order to stop such kind of disorder, of course, it would be needed insane screams and strikes as powerful as lightning.

9. Yoshlikning quvvatli to'lqinlari ularning barchasini bir bahor yomg'iri kabi yuvib ketmaganmidi?. [6, p 18]

Разве мощные волны молодости не смыли все как весенний дождь?

Would not the powerful waves of youth wash all of them away like a spring rain?

In these sentences, there should be no loss of meaning, and the aim, which is often realized, is to make the translation more effective as well as more elegant than the original.

10. Sopol piyolada choy ichib yurgan choyxo`rlar o`ris poshshoning piyolasida choy ichaylik, deb samovarga aridek yopirildi. [2, p 2]

Любители чая, привыкшие пить его из керамической пиаль бросились на самовар словно пчель чтобы попробовать чай из чашки русского паши.

The tea-drinkers, who were drinking tea in a ceramic bowl, rushed to the samovar to drink tea in the cup of the Russian tsar like bees.

11.- Isitmangiz ancha baland tinchroq joyda yotib, dam olib bir kungina davolansangiz otdek bo'lib ketasiz, - dedi keksa fledsher. [2, p 12]

«Если бы вы приляжете в более спокойном месте и отдохнёте бы в течение дня, вы будете как лошадь», - сказал старый фельдшер.

An old medical person mentioned: "If you want to lie down in a much quieter place and get some rest and treatment for a day, you will become healthy like a horse."

12. Uni ko`rib chehram yorishgandek bo 'ldi. "Odam taftini odam oladi” deganlari shu bo 'lsa kerrak-da. [2, p 12]

Seeing him, my face is brightening like the sun. There is a wonderful and true saying, "Man needs man."

Когда я его увидел, мое лицо словно просветлело. Вот и вправду говорят: “Человек жив человеком».

All translation must be in some degree both communicative and semantic, social and individual. Nothing is more obvious than the creation of a translation, whether communicative, literal or semantic one, must be its measure of accuracy, value and importance.

13... Buyoqda singlisi tag `in "bir ishkal” ortirdi: shoshqaloq bodomga o ‘xhab” erta gullab qo yib, sovuq urib ketgan " qizlarning qismati shunaqa bo ladi uzi. [7, p 40]

И тут еще сестра заварила кашу: "Словно торопливый миндаль что рано расцветает $u$ замерзает» девичья судьба, она такая.

...His sister aggravated the problem again like a "hurried almond", which blooms early in spring and die in the cold. I can compare girls' fate with it.

In the below translation, any simile, image or comparison should usually be as familiar to the target language as to the source language reader. We are assuming that the three local referents are more common in Uzbek, Russian and English.

14. Hali ishq nimaligini bilamagan yurakda juda nozik, shamchiroqdek bir o`t - sevgiga chanqoq o`t yiltillab turarkan. [7, p 47]

В сердие, еще не знающем, что такое любовь, сияет очень нежный огонь, огонь словно свеча, что жаждет любви.

A very delicate, candle-like sweet heart is glittering in order to fall in love without knowing what the love is.

Some other well-known similes you will often hear are:

+ means in three languages the same meaning, complete correspondences.

- means only partial conformities. 
The Art of Translating Similes in the Works of Central Asian Writers

\begin{tabular}{|c|c|c|}
\hline English & Uzbek & Russian \\
\hline +As cute as a kitten & +Mushukchadek muloyim & +Милый как котенок \\
\hline +As happy as a clam & -Tanga topgan quldek xursand & +Счастлив, как моллюск \\
\hline+ As light as a feather & + Patdek yengil & +Лёгкий как пёрышко \\
\hline+ As blind as a bat. & +Ko'rshapalakdek ko'r & +Слепой, как летучая мышь \\
\hline+ As bright as a button & -Tongdek yorug' & +Яркая, как пуговица \\
\hline+ As shiny as a new pin & -Tillodek yaltiramoq & +Блестит как новая булавка \\
\hline+ As cold as ice. & +Muzdek sovuq. & +Холодный как лёд \\
\hline+ As common as dirt & Juda oddiy & $\begin{array}{l}\text {-Как три копейки (обычный, } \\
\text { простой) }\end{array}$ \\
\hline -As cool as a cucumber & -Go'l kabi befarq & -Спокойный как удав \\
\hline+ As hard as nails.. & +Mixdek qattiq & +Твердый как гвоздь \\
\hline +As hot as hell. & +Do'zax olovidek issiq. & +Жарко как в аду \\
\hline+ As innocent as a lamb & + Begunoh quzichoq & +Невинный, как ягненок. \\
\hline+ As tall as a giraffe & -Terakdek uzun & +Такой же высокий, как жираф \\
\hline+ As tough as nails & +Mixdek baquvvat & +Крепкий как гвоздь \\
\hline+ As white as a ghost. & -Murdadek oqargan & +Белый, как привидение \\
\hline -As sweet as sugar. & + Asaldek totli & +Сладкий как мёд \\
\hline+ As black as coal & +Ko'mirdek qop-qora & +Черный как уголь \\
\hline
\end{tabular}

As with a lot of figurative language, when talking to someone from another region or someone not speaking in their native language they might not get the meaning of many similes. Similes can make our language more descriptive and enjoyable. Writers, poets, and songwriters make use of similes often to add depth and emphasize what they are trying to convey to the reader or listener. Similes can be funny, serious, mean, or creative. The translators must put some aim to reflect the spirit and image of the period in the language of translation as if it is the original. The realization of this goal depends, of course, on the translators and their skill.

Following are some more examples of similes regularly used in writing:

\begin{tabular}{|c|c|c|}
\hline ENGLISH & UZBEK & RUSSIAN \\
\hline+ You were as brave as a lion & +Sherdek qo'rqmas & +Смелый как лев \\
\hline +They fought like cats and dogs. & +It mushukdek urushmoq & +Как кошка с собакой \\
\hline $\begin{array}{l}+\mathrm{He} \text { is as funny as a barrel of } \\
\text { monkeys }\end{array}$ & -Masxarabozdek quvnoq & $\begin{array}{l}+ \text { смешно }, \\
\text { обезьянами }\end{array}$ \\
\hline +This house is as clean as a whistle & -Yog' tushsa yalagudek toza & +чист как стеклышко \\
\hline+ He is as strong as an ox. & +Hukizdek baquvvat & +сильный, как бык \\
\hline $\begin{array}{l}+\mathrm{I} \text { am so thirsty that my throat is as } \\
\text { dry as a bone }\end{array}$ & $\begin{array}{l}\text { +Chanqagandan og'zim qurub } \\
\text { qolibdi. }\end{array}$ & +сухой, как кость \\
\hline $\begin{array}{l}\text { +That is as easy as shooting fish in } \\
\text { a barrel. }\end{array}$ & -Xamirdan qil sug'urgandek oson. & $\begin{array}{l}\text { +так же просто, как стрелять } \\
\text { рыбу в бочке }\end{array}$ \\
\hline
\end{tabular}




\begin{tabular}{|l|l|l|}
\hline $\begin{array}{l}\text { +This contract is as solid as the } \\
\text { ground we stand on }\end{array}$ & $\begin{array}{l}\text {-Ushbu shartnoma o'z kuchini } \\
\text { yo'qotmagan }\end{array}$ & $\begin{array}{l}\text { +такая же твердая, как земля, на } \\
\text { которой мы стоим. }\end{array}$ \\
\hline $\begin{array}{l}\text { +Don't just sit there like a bump on } \\
\text { a log. }\end{array}$ & -Nina ustida o'tirmoq & $\begin{array}{l}\text { +Не сиди там, как шишка на } \\
\text { бревне }\end{array}$ \\
\hline $\begin{array}{l}\text { +They are as different as night and } \\
\text { day. }\end{array}$ & $\begin{array}{l}\text { +Kun bilan tundek bir biridan farq } \\
\text { qiladi }\end{array}$ & +Различны как день и ночь \\
\hline +She is as thin as a rake & +Chupdek ozg'in & +Тонкая(худая) как палка \\
\hline +Last night, I slept like a log. & +Taxtadek qotibman & -Крепко спать \\
\hline $\begin{array}{l}\text { +This dress is perfect because it } \\
\text { fits like a glove. }\end{array}$ & -Uzukka ko'z qo'ygandek & +Сидит как перчатка \\
\hline $\begin{array}{l}\text {-They wore jeans, which made me } \\
\text { stand out like a sore thumb }\end{array}$ & -Tillodek ko'zga tashlanmoq & $\begin{array}{l}\text {-Выделяться как больной палец } \\
\text { (Бросаться в глаза) }\end{array}$ \\
\hline $\begin{array}{l}\text { +My love for you is as deep as the } \\
\text { ocean }\end{array}$ & $\begin{array}{l}\text {-Sizga bo'lgan muhabbatim } \\
\text { cheksizdir }\end{array}$ & +глубокая, как океан. \\
\hline
\end{tabular}

We believe that translation is an exceptionally difficult and challenging job; that it demands the translator to become very careful in choosing and selecting words, word phrases, sentences by comparing the languages.

The translator needs in-depth knowledge in translating and then gives the meaning in the target language. The point of the translation is a bridge between national and international coloring. By comparing three languages as Uzbek, Russian and English sometimes we see no differences, sometimes very different words but close its meanings.

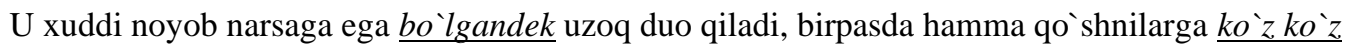
qilib chiqadi, shundoq "mehribon" o'g li borligini aytib maqtanadi. [8, p 18]

She prays for a long time as if she has something unique, which was brought by her son. Taking this one, she began boasting that she has "very generous" son.

For.eg. Qazisan, qartasan asl zotingga tortasan. As the old cock crows, so doth the young, As the tree, so the fruit. [4, p.101] Яблоко от яблони не далеко падает.

Results and discussion. In the lessons of Discourse analyses, Theory and Practice of Translation and Stylistics, students try to read writers' masterpieces by comparing three languages as, Russian, Uzbek and English. Any literary work appears on the national ground, reflects national problems, features and at the same time the problems common to all humankind. Passing from one nation to another literature enriches and extends the notion of peoples about each other. It is one of the most difficult cases to convey national coloring.

A linguistically difficult sentence maybe defined as a sentence where one to one translation is impossible and the unit of translation is likely to be at least sentence to sentence. The translator must not use a word or phrase that sounds unnatural or artificial to him. Translation is complicated by its own use of two kinds of units. The grammatical scale of morpheme, word, phrase, sentence and paragraph is generally known. The lexical scale which is perhaps more important in translation.

Some stylistic devices as proverbs and simile, we found out very interesting details and compared them with English language. We worked hard with the translation of Ch. Aitmatov's literary work "Jamila" and tried to find out the main ideas and specific features of his novel.

1 -Bir tomoni yangam, ikkinchi tomoni mendan bir oz katta, lekin biz xuddi tengqur do'stlardek edik. [3, $p 88]$ - In one hand she was my sister-in-law, in the other hand, she was a bit older than me, but we were friends like the same age.

2 - Meni "kichkina bola"deb o'z ukasidek erkalatganini aytmaysizmi. [3, p 88]

- She fondled me as if I was her little brother and called me "kiddy".

3 -Obbo siz-ey,- dedi u,- agar to'rt muchcham sog' bo'lib, qo'limdan kelsa, o'zimoq ilgargidek qoplarni aravaga irg'itib-irg'itib, otlarni choptirib ketmasmidim. [3, $p$ 89]

- "Oh, it is a pity!" - said he, "If I were really in good health, I would throw the heavy sacks to the carts and ride on horses by myself as previous time of mine"

4 -To'g'ri chol-kampirlarning cho'chiganicha bor edi: Jamila juda sho'x yosh bolaga o'xshardi. [3, $p 93]$

- It was undoubtedly that the old couples were in trouble because Jamila was very mischievous, naughty and she was like a child. 
5 -Haydasa haydayversin, nima, bo'ri yeb ketarmidi! - deb xuddi aravakashlardek chirt etkizib tupurdim-da, qamchini sudraganimcha salmoq bilan qadam tashladim. [3, p 93]

-I can easily go, I am not afraid of anything!- he said. He spit sharply like a carter and began to march by holding the crop.

6 - Biz u bilan apoq-chapoq, bir biridan hech narsani yashirmaydigan, sirdosh do'stlardek edik. [3, $p$ 95]

- We were on friendly terms with her and we could not hide any secrets like faithful and confident friends.

7 - Ichagi uzilib kulgan Jamila baliqdek sirg'anib, qo'ldan chiqib ketar, xotinlarini yordamga chaqirib qichqirar, lekin ular qiy-chuv ko'tarib, o'zlarining suvda oqib borayotgan ro'mollarini ushlash bilan ovora edilar. [3, p 95]

- Bursting into laughter, Jamila tries to act like a fish in order to escape from hands by shouting to help others. Nevertheless, the women were yielding and screaming by attempting to catch their kerchiefs, which were floating in the stream.

8 - Qayoqlarda tentirab yuribsan bolam, sochlaring o'sib, devonaga o'xshab ketibsan-ku. [3, p 90]

- Where have you been wandering, like a foolish one, darling? Your hair has grown and untidy.

Conclusion. The translator needs the same in-depth knowledge to re-encode the meaning in the target language. In fact, in general, translators' knowledge of the target language is more important, and needs to be deeper, than their knowledge of the source language. For this reason, most translators translate into a language of which they are native speakers. The basic determination of translation is to reproduce various types of texts, comprising literary, religious, scientific, philosophical texts etc. in another language and thus making them available to wider readers, to a greater number of target audience and to bring the world closer.

For this reason, the translator plays an important role as a bilingual or multi-lingual cross-cultural transmitter of culture and truths by attempting to interpret concepts and speech in a variety of texts as faithfully and accurately as possible.

Learning proverbs, quotations, sayings need to be fostered so that learners can cope with more and more about them, and deal with them efficiently: quickly, appropriately and skillfully. There are various reasons why our students remember some proverbs better than others: the nature of the proverbs, stylistic devices themselves, under what circumstances they are learnt, the method of teaching and so on. Working with them language learners learn not only a foreign language, but also a foreign language also comparing three languages.

\section{References}

1. Ahmad Said "Jimjitlik", Toshkent, 1989.

2. Ahmad Said "Kiprikda qolgan tong". Sharq- Toshkent, 2008.

3. Aytmatov Chingiz. "The best love stories "Jamila" T- 2017 "Yangi asr avlodi"

4. Kambarov N. Universal lug'at - ma'lumotnoma, Universal handbook and dictionary for English learners and translators, Toshkent, "Turon-Iqbol", 2014.

5. Zoya Proshina. Theory of Translation, (English and Russian) Vladivostok Far Eastern University Press, 2008.

6. Cho 'lpon "Kecha va kunduz", Toshkent, 2007.

7. O'tkir Hoshimov. "Sevgi qissalari”. Toshkent "O`zbekiston”, 2013.

8. O'tkir Hoshimov "Dunyoning ishlari", Toshkent, Sharq nashriyoti, 2005.

9. Peter Newmark. (1988) Approaches to translation. Shanghai foreign language education press.

10. Iriskulov M.T., Kambarov N.M., Tukhtaeva K.D. Translation Theory and Practice. Course book, Tashkent: 2020 